\title{
Accidents Related to the 2014 Rains and Their Socio-Economic Consequences in the City of Abidjan: The Case of the Municipalities of Abobo and Attécoubé (Côte D’Ivoire)
}

\author{
Brou Kamenan Marcel1 ${ }^{1}$, Adomon Abodou Athanase ${ }^{2}$, Konan Kouadio Joël ${ }^{3}$, Alla Della André ${ }^{1}$ \\ ${ }^{1}$ University Félix Houphouët, Boigny, Côte d'Ivoire \\ ${ }^{2}$ University Péléforo Gon Coulibaly, Korhogo, Côte d'Ivoire \\ ${ }^{3}$ Institute of Tropical Geography, Félix Houphouët-Boigny University, Boigny, Côte d'Ivoire \\ Email: kamenanlermarcel@ymail.com, athananseadomo@yahoo.fr, athanaseadomon@upgc.edu.ci, akanzakoua@live.fr, \\ gnalladella@gmail.com
}

How to cite this paper: Marcel, B. K. Athanase, A. A., Joël, K. K., \& André, A. D. (2021). Accidents Related to the 2014 Rains and Their Socio-Economic Consequences in the City of Abidjan: The Case of the Municipalities of Abobo and Attécoubé (Côte D'Ivoire). Journal of Geoscience and Environment Protection, 9, 195-208. https://doi.org/10.4236/gep.2021.93012

Received: January 18, 2021

Accepted: March 27, 2021

Published: March 30, 2021

Copyright $\odot 2021$ by author(s) and Scientific Research Publishing Inc. This work is licensed under the Creative Commons Attribution International License (CC BY 4.0).

http://creativecommons.org/licenses/by/4.0/ (c) (i) Open Access

\begin{abstract}
The urban environment is confronted with recurring calamities including floods, landslides and forced escapes of populations during periods of rain. In Côte d'Ivoire, the municipalities of Abobo and Attécoubé suffered enormous material and human damage following the torrential rains of 2014. These urbanized areas are built on large plateaus bordered by thalwegs where $61 \%$ of these areas have no drainage network, thus facing a lack of sanitation. Moreover, topographical, rainfall, anthropogenic and technical conditions are factors explaining the occurrence of natural disasters and their consequences in the said communes. The objective of this article is to assess the socio-economic impact of the occurrence of hazards. It focuses on the identification of risk sectors in the municipalities of Abobo and Attécoubé and the material, human and economic consequences that result from rain accidents.
\end{abstract}

\section{Keywords}

Abobo, Attécoubé, Disasters, Environment, Thalwegs

\section{Introduction}

These last decades are increasingly disturbed by both natural and anthropogenic phenomena that continue to disrupt the environment. Floods, mass movements, coastal erosion, cyclones and hurricanes, earthquakes, technological accidents, tsunamis are disasters that cause more and more damage in the world. Faced 
with such threats to cities, particularly those in developing countries with high population growth, several authors including Bailly (1996), D’Ercole (1996), Robin and Hauhouot (1999a), Robin and Hauhouot (1999b), Veyret and Nancy (2004), Abé (2005), Ramade (2006), and Alla (2013) addressed the issue of natural hazards and consequences. Others, such as Assako (1996), note that floods and mass movements in Cameroon are a real concern for cities located in areas with high rainfall rates because at the base of many damages such as in Abidjan, the economic capital of Côte d'Ivoire.

In 2014, the municipalities of Abobo and Attécoubé, which lie on a dissected plateau, a very rugged sheep, were prey to hydrometeorological incidents. They are located in the northern part of the city of Abidjan (Figure 1).

Indeed, urbanization in these two municipalities extends beyond the constructible and developed areas to non constructible areas to the detriment of the rules of urbanism and construction. As a result, pockets of precarious and spontaneous housing appear due to demographic pressure and impoverishment. But in environments where rainfall is abundant; more than $1800 \mathrm{~mm}$ of rain per year and where topographic, anthropogenic and technical conditions no longer follow the rhythm and the specifications of the existing urbanisation (Alla, 2013); (Brou, 2008); (Brou, 2015) and (Tamboura, 2008); the increasing vulnerability of the population and the degradation of the immediate living environment are legion; floods and mass movements are the result of frequent landslides and landslides.

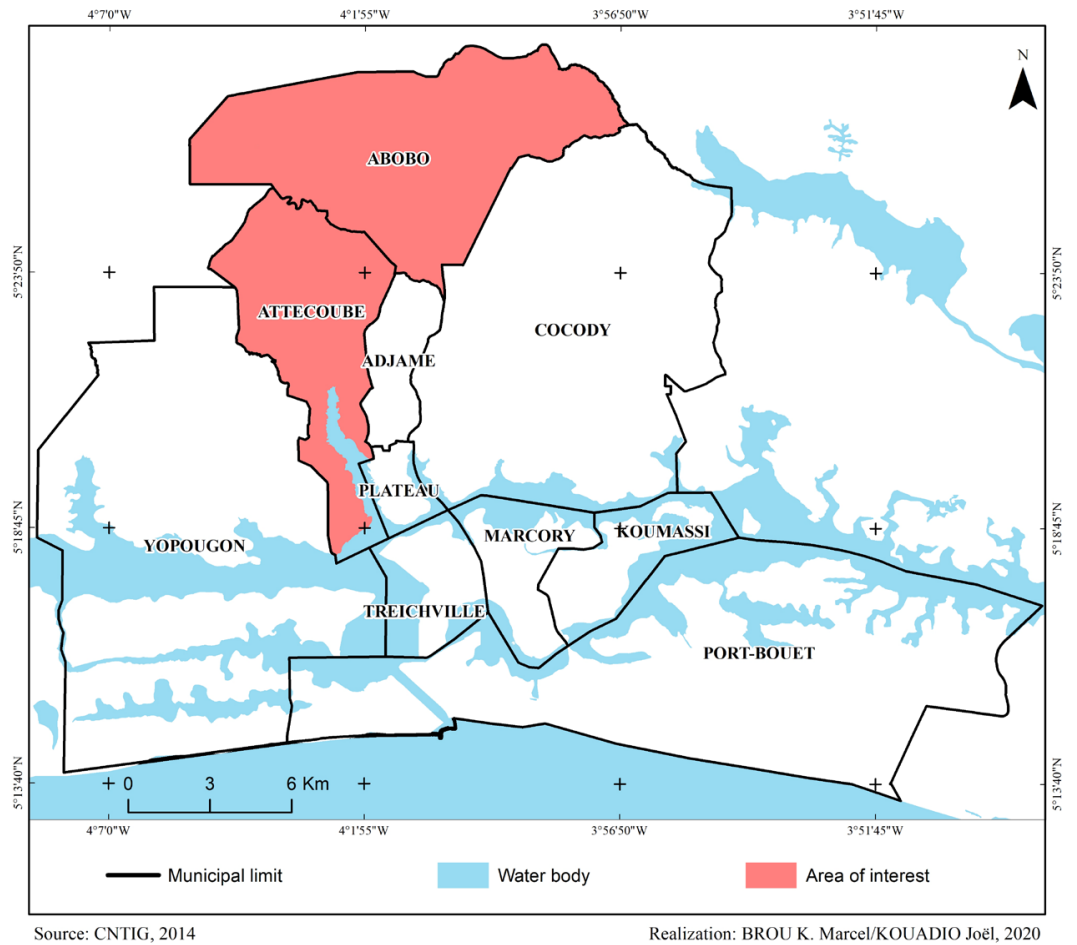

Figure 1. Geographical situation of the municipalities of Abobo and Attécoubé in Abidjan. 
These municipalities suffered the disastrous consequences of heavy rains during May-July 2014. Despite the actions taken by the authorities to reduce the harmful consequences of the heavy rains, the situation remains unchanged.

The objective of this article is to assess the socio-economic impact of the occurrence of hazards. It focuses on the identification of risk sectors in the municipalities of Abobo and Attécoubé and the material, human and economic consequences that result from rain accidents.

\section{Method}

The methodological approach is a hypothetico-deductive approach based on the literature search, the field observation carried out from 2014 to 2015 and interviews with resource persons (local populations and municipal authorities).

Concerning the documentary research, the information collected relates to existing natural phenomena and their consequences.

With the population surveys, we were able to identify the most vulnerable areas and exposed to natural hazards. All the neighborhoods of the two communes have travelled. This allows us to know the risks that people face during each rainy season. To identify the socio-economic consequences on the immediate environment and on populations.

For further information, interviews are held with local authorities. In particular, agents of the technical services, environment and population of the town halls. These questions focused on the site where the populations, habitat types, the different phenomena that occur, the moments of rain, their consequences and their interventions are built. (Assistance to populations, risk management techniques and recovery strategies, etc.). All the data have been processed and restored in the form of tables, maps which have been the subject of brief analyses.

\section{Results and Analysis}

\subsection{Identification of Risk Sectors in the Municipalities of Abobo and Attécoubé}

\subsubsection{Abobo, a Rugged Site}

Located in the north of the city of Abidjan, the municipality of Abobo extends over a plateau site broken down on sides by basins called natural depressions. These are natural rainwater collection areas, which are therefore difficult to urbanize. There are about 30 of them in the current urban area. The sizes of these depressions vary between 100 and 130 meters for a depth of up to five meters as shown in Figure 2.

This municipality of Abobo has 18 storm basins and 10 ravines as shown in Table 1. Among these storm basins, 8 critical basins are likely to cause enormous damage. In particular, the Houphouët-Boigny, Agnissankoi, Red plate, Cayman Lake, Pays-Bas, Glacier, Monastery, Bougounisso.

The conditions of occurrence of the hazards of Attécoubé are identical to 
Table 1. Identification of the different risk areas in the municipality of Abobo.

\begin{tabular}{|c|c|}
\hline AREAS AND SECTORS AFFECTED & NEIGHBORHOODS \\
\hline \multicolumn{2}{|c|}{ STORM BASINS } \\
\hline Banco & Banco \\
\hline 2nd Stop & Abobo 2nd Stop \\
\hline Houphouët Boigny (critical) & 4 floors near the l'H.P.B \\
\hline Nest of the Doves & Akéikoi \\
\hline Agnissankoi (critical) & Avocatier \\
\hline Bougounisso (critical) & PK 18 \\
\hline Red plate (critical) & PK 18 \\
\hline N’Dotré & N’Dotré \\
\hline Cayman Lake (critical) & Anonkoua \\
\hline Pays-Bas (critical) & Anonkoua 2 \\
\hline Glacier (critical) & Avocatier \\
\hline Nanti & Anador \\
\hline Samaké & Samaké \\
\hline Monastery (critical) & Monastery \\
\hline sos & Housing SOS \\
\hline Gendarmerie & Abobo Gagnoa station \\
\hline Pharmacy Maténé & Abobo Avocatier \\
\hline Sacred Forest & Abobo Banco up to PK 18 \\
\hline \multicolumn{2}{|c|}{ RAVINES } \\
\hline Houphouët Boigny & Colatier housing behind 4 floors \\
\hline Green Island & Behind hospital Houphouët Boigny \\
\hline Deposit 09 & PK 18 behind college ISSEA \\
\hline Colombie & Behinf the station la S7 \\
\hline Sagbé & Behinf the rail \\
\hline Agbékoi & Agbékoi \\
\hline Plate & Plate \\
\hline N’Dotré & N’Dotré \\
\hline Nangui Abrogoua University & Anador extension \\
\hline Akéikoi & Akéikoi \\
\hline
\end{tabular}

Source: Our surveys 2014 and 2015.

those of the previous zone. However, site conditions are different from land use and development conditions. 


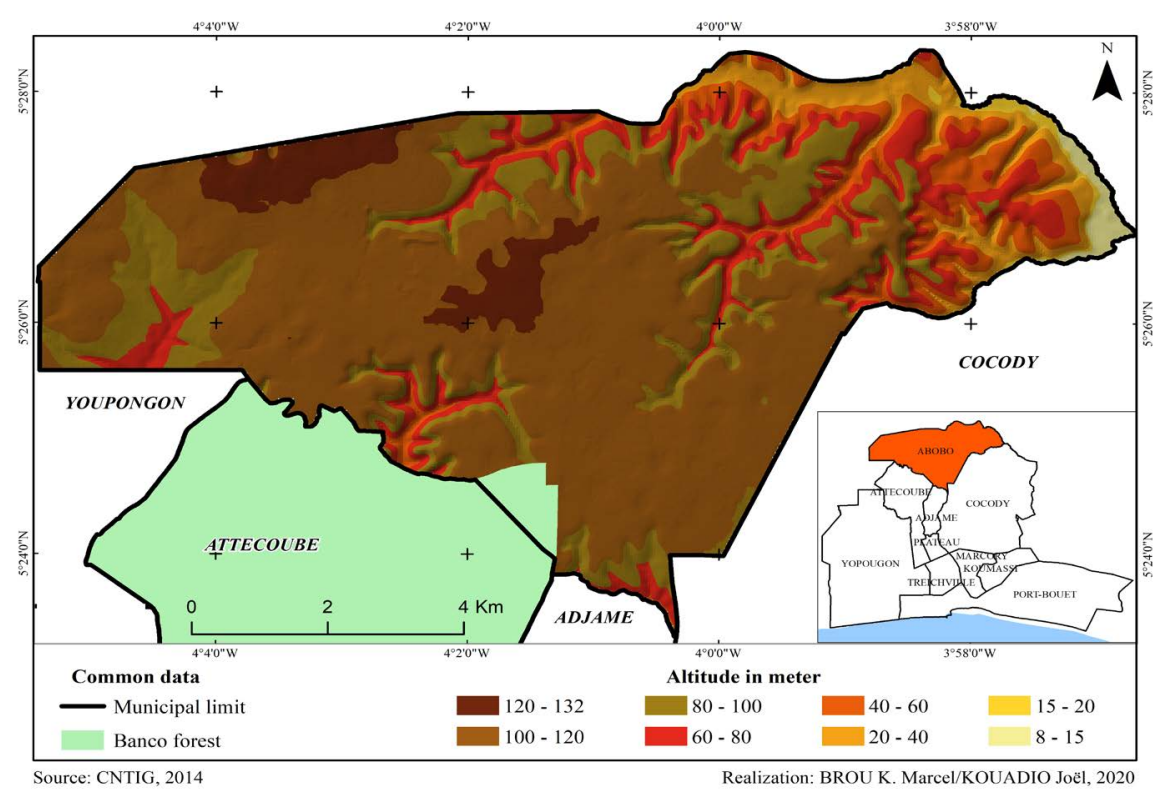

Figure 2. The Abobo relief.

\subsubsection{Attécoubé, a Site with Pronounced Topographical Constraints}

The site of Attécoubé is a plateau relief cut in half by the bay of Banco (river). This relief has different characteristics from one cardinal point to another. To the east, it is separated from the interfluve of Adjamé-centre by a valley whose encashment is 35 meters; this gives it the appearance of a large mound elongated in the north-south direction. This relief is itself composed of two interfluves divided by a very deep valley of the order 50 - 60 meters. It starts from the original site of Attécoubé by passing by the Marian Shrine, the Fairmont city to the bay of the banco by a steep. To the west of the bay of the banco, we note the presence of valleys with steep slopes with relatively wide bottoms. The ramifications of the eastern ledges of the banco plateau have reduced the altitudes of the summits from 40 - 50 to 50 - 60 meters.

To the south a flat surface of 30 - 40 meters more or less favorable to urbanization. Table 2 and Figure 3 provide an overview of the risk areas and terrain of Attécoubé.

From the above, we consider that Abobo and Attécoubé are two municipalities established on potentially dangerous sites where risks of landslides and floods in case of rain are proven. Even worse, in these urbanized areas, we have noticed a rough servicing of land intended for the construction of habitats, a regular lack of sanitation and irregular urban development (Adomon and al, 2018). Such failures expose any urbanized area and said environment to serious consequences in the event of natural disasters.

\subsection{The Consequences of Rain Accidents in the Most Affected Neighbourhoods of the Two Municipalities}

The heavy amount of rain during the month of June $(89 \mathrm{~mm} /$ daily rain and 946.1/monthly rain) caused multiple accidents in the Abidjan District. These are 


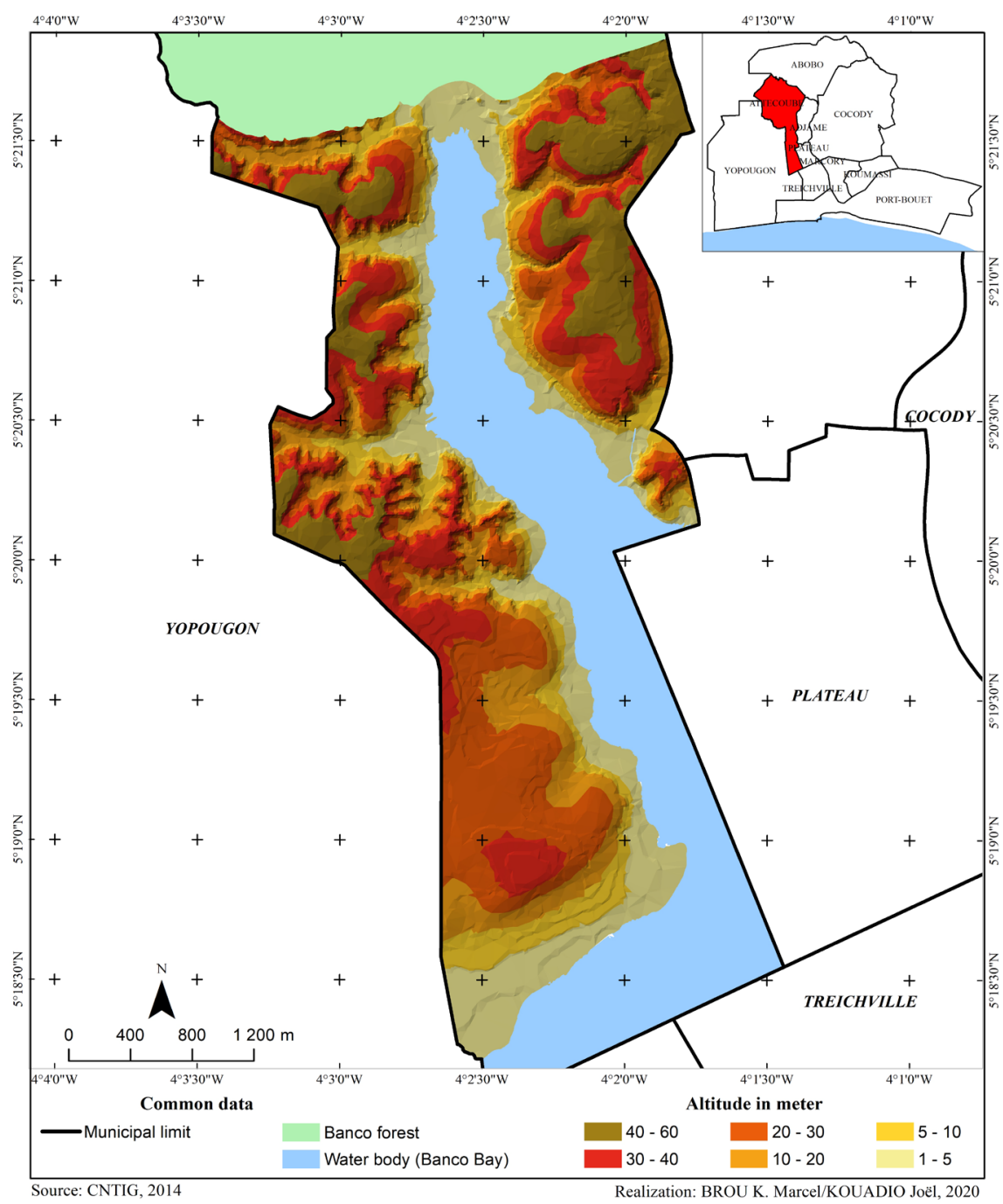

Figure 3. The relief of Attécoubé.

Table 2. Identification of the different risk areas in the municipality of Attécoubé.

\begin{tabular}{cc}
\hline NEIGHBORHOODS & AREAS AND SECTORS AFFECTED \\
\hline Agban-Attié & The whole neighborhood (versant) \\
CFI & The whole neighborhood (versant) \\
Santé III & Deinde (versant) \\
Gbebouto & Pharmacy Rehoboth Boulevard of peace, complex (natural depression) \\
Boribana & Lagoon edge \\
Espoir & Canal vigou sector \\
Lagune & Lagoon edge \\
Nematoulaye & All along the hillsides \\
\hline
\end{tabular}

Source: Our surveys 2014 and 2015.

mainly floods in Abobo on the one hand and landslides and mudslides on the other hand in Attécoubé. 


\subsubsection{Consequences of Floods in the Neighbourhoods of the Municipality of Abobo in 2014}

They concern the loss of life, injuries, material damage, destruction of homes and economic activities as shown in Tables 3-6.

From the analysis of Tables 3-6, it appears that the floods had harmful and catastrophic effects on the environment and the living environment of the populations in the municipality of Abobo. Worse still, losses of human lives and property damage were reported in the said municipality following the landslides. Table 7 and Table 8 give an overview of these losses in human lives and property damage.

\subsubsection{The Consequences of Landslides and Landslides in the Municipality of Attécoubé}

The municipality of Attécoubé is a high risk area due to the dangerous landslides that occurred there. With the support of local authorities, we have identified the consequences of this natural disaster as shown in Tables 9-11.

As for landslides, their effects are more noticeable at Attécoubé with the corollary of significant material damage as shown in Tables 12-14.

In total, it should be remembered that the rains of 2014 caused more deaths in the commune of Attécoubé than Abobo. We counted 07 in Abobo and 16 in Attécoubé. These torrential rains made more than 2000 displaced. On economic activities, the rain caused the destruction of products from the various stores located at the edge of the sewerage and drainage networks. The destruction of goods and materials from the shops during and after the floods. Finally, it resulted in the destruction of economic infrastructure in both municipalities.

Table 3. Overview of the economic damage provoked by the floods in Abobo.

\begin{tabular}{cccc}
\hline NEIGHBOURHOODS & RAIN IN (mm) & DAMAGE RECORDED & DATES \\
\hline Assin Monastery & 58.0 & 16 stores destroyed & Thursday 12 $2^{\text {th }}$ June 2014 \\
\hline
\end{tabular}

Source: Our surveys 2014 and 2015.

Table 4. Overview of human lives lost in the Abobo Floods.

\begin{tabular}{cccc}
\hline Neighbourhoods & Rain in $(\mathrm{mm})$ & Number of Deaths & Dates \\
\hline Biabou & 89.0 & 01 & Friday $06^{\text {th }}$ June, 2014 \\
\hline Bocabo & & 01 & \\
Celeste & 58.0 & 01 & Thursday $12^{\text {th }}$ June 2014 \\
Monastery & & 01 & \\
\hline Cayman Lake & 74.0 & 01 & Sunday $15^{\text {th }}$ June, 2014 \\
\hline Bourguinisso & 58.0 & 01 & Sunday $29^{\text {th }}$ June, 2014 \\
Green Island & & 01 & \\
\hline
\end{tabular}

Source: Our surveys 2014 and 2015. 
Table 5. Overview of material damage provoked by Floods in High-Risk Neighbourhoods in Abobo.

\begin{tabular}{|c|c|c|c|}
\hline NEIGHBOURHOODS & RAIN IN (mm) & DAMAGES & DATES \\
\hline $\begin{array}{l}\text { PK 18, site known as the } \\
\text { Red Plate Stormwater } \\
\text { Outlet on the N'Dotré Road }\end{array}$ & 88.0 & $\begin{array}{l}\text { Fences fallen under the weight of } \\
\text { water; houses damaged; Several } \\
\text { families put to the shelter; Huge } \\
\text { losses in furniture and various. }\end{array}$ & $\begin{array}{c}\text { Tuesday } 03^{\text {rd }} \\
\text { June } 2014\end{array}$ \\
\hline Pays-Bas in Anonkoi-Kouté & 89.0 & $\begin{array}{l}\text { At least } 10 \text { houses underwater } \\
\text { with extensive property damage. } \\
03 \text { houses destroyed; } 40 \text { flooded } \\
\text { habitats; A submerged CIE } \\
\text { Transformation Station }\end{array}$ & $\begin{array}{l}\text { Friday } 06^{\text {th }} \\
\text { June, } 2014\end{array}$ \\
\hline $\begin{array}{l}\text { Basin Monastery road } \\
\text { to Abobo-Baoulé }\end{array}$ & 58.0 & $\begin{array}{c}04 \text { houses destroyed; } 10 \text { flooded } \\
\text { houses; Losses in property; } \\
\text { Populations held hostage } \\
\text { by the waters. }\end{array}$ & $\begin{array}{c}\text { Thursday } 12^{\text {th }} \\
\text { June } 2014\end{array}$ \\
\hline $\begin{array}{l}\text { Assomin PK } 18 \\
\text { Cayman Lakes }\end{array}$ & & At least 20 flooded houses. & \\
\hline $\begin{array}{l}\text { Dove Nest Basin at } \\
\text { BC Neighbourhoods, } \\
\text { Akéikoi Road }\end{array}$ & 89.0 & $\begin{array}{l}\text { At least } 10 \text { houses flooded, } \\
\text { populations taken hostage } \\
\text { because of access roads closed } \\
\text { by water, loss of property. }\end{array}$ & $\begin{array}{l}\text { Friday } 06^{\text {th }} \\
\text { June, } 2014\end{array}$ \\
\hline $\begin{array}{l}\text { Houphouët Boigny Basin } \\
\text { in Neighbourhoods C in } \\
\text { front of General Hospital }\end{array}$ & & $\begin{array}{l}\text { Severe flooding of the site, } \\
\text { at least } 10 \text { flooded habitats. }\end{array}$ & \\
\hline $\begin{array}{l}\text { Road Gendarmerie } \\
\text { Brigade-CampCommando }\end{array}$ & 58.0 & $\begin{array}{l}\text { Several vehicles under water } \\
\text { of about } 2 \text { meters, } \\
01 \text { mosque flooded. }\end{array}$ & $\begin{array}{c}\text { Thursday } 12^{\text {th }} \\
\text { June } 2014\end{array}$ \\
\hline $\begin{array}{l}\text { Expressway in front } \\
\text { of Mobil Station }\end{array}$ & & Impraticable way & \\
\hline Kennedy Sector & 74.0 & $\begin{array}{l}16 \text { houses destroyed, } \\
28 \text { flooded and } \\
01 \text { abandoned schools. }\end{array}$ & $\begin{array}{l}\text { Sunday } 15^{\text {th }} \\
\text { June } 2014\end{array}$ \\
\hline
\end{tabular}

Source: Our surveys 2014 and 2015.

Table 6. Overview of the floods in the municipality of Abobo in 2014.

\begin{tabular}{|c|c|c|c|}
\hline NEIGHBOURHOODS & RAIN IN (mm) & NUMBER OF CLAIMS & DATES \\
\hline Monastery & 58.0 & 131 & Thursday $12^{\text {th }}$ June 2014 \\
\hline Agnissankoi & \multirow{3}{*}{89.0} & 62 & \multirow{3}{*}{ Friday $06^{\text {th }}$ June, 2014} \\
\hline & & & \\
\hline Nest of doves & & 189 & \\
\hline Houphouët Boigny & \multirow{3}{*}{58.0} & 132 & Thursday $12^{\text {th }}$ June 2014 \\
\hline & & & \\
\hline Nanti-Dokoui & & 69 & Sunday $29^{\text {th }}$ June, 2014 \\
\hline Glacier Bocabo & 74.0 & 151 & Sunday $15^{\text {th }}$ June, 2014 \\
\hline Banco & 58.0 & 53 & Thursday $12^{\text {th }}$ June 2014 \\
\hline Pays-Bas & 74.0 & 130 & Sunday $15^{\text {th }}$ June, 2014 \\
\hline
\end{tabular}




\section{Continued}

\begin{tabular}{cccc}
\hline Abobo Baoulé & & 27 & \\
$\begin{array}{c}\text { Abobo 2 } \\
\text { eame }\end{array}$ arrêt & 58.0 & 122 & Thursday 12 ${ }^{\text {th }}$ June 2014 \\
Cayman Lake & & 121 & \\
\hline Anokoi Kouté & 89.0 & 79 & Friday 06 ${ }^{\text {th }}$ June, 2014 \\
\hline Red plate & 88.0 & 60 & Tuesday 03 ${ }^{\text {rd }}$ June 2014 \\
\hline & Total 1326 claims & \\
\hline
\end{tabular}

Source: Our surveys 2014 and 2015.

Table 7. Overview of material damage following the landslides at Abobo in 2014.

\begin{tabular}{cccc}
\hline NEIGHBOURHOOD & RAIN IN $(\mathrm{mm})$ & DAMAGES & DATES \\
\hline Biabou & 89.0 & $\begin{array}{c}\text { 02 housies destroyed } \\
\text { 03 houses destroyed; } \\
\text { Losses in furniture }\end{array}$ & Friday 06 ${ }^{\text {th }}$ June 2014 \\
BgbekoI-Clouetcha & 58.0 & More than 10 houses & collapsed \\
Celeste & 03 houses destroyed & Thursday 12 \\
& & & \\
\hline
\end{tabular}

Source: Our surveys 2014 and 2015.

Table 8. Overview of the victims of the various neighbourhoods affected by the landslides in Abobo.

\begin{tabular}{cccc}
\hline NEIGHBOURHOOD & RAIN IN $(\mathrm{mm})$ & NUMBER OF CLAIMS & DATES \\
\hline Biabou & 89.0 & 70 & Friday 06 ${ }^{\text {th }}$ June 2014 \\
Bocabo & & 130 & Thursday $12^{\text {th }}$ June 2014 \\
\hline Agbekoi-Clouetcha & 58.0 & 54 & \\
Celeste & 80 & \\
Total & 334 claims & \\
\hline
\end{tabular}

Source: Our surveys 2014and 2015.

Table 9. Overview of loss of life by neighbourhood following landslides in Attécoubé.

\begin{tabular}{|c|c|c|c|c|c|}
\hline NEIGHBOURHOODS & $\begin{array}{l}\text { RAIN IN } \\
\quad(\mathrm{mm})\end{array}$ & $\begin{array}{c}\text { NUMBER } \\
\text { OF DEATHS }\end{array}$ & DATES & VICTIMS & NATIONALITY \\
\hline Banco nord & 84.9 & 01 & $05^{\text {th }}$ June 2014 & $\begin{array}{l}\text { FOROMO Tokpa } \\
\text { Eugène ( } 24 \text { years) }\end{array}$ & Guinean \\
\hline $\begin{array}{c}\text { Santeé } 3 \\
\text { (Safari sector) }\end{array}$ & 71.1 & 04 & $\begin{array}{l}\text { Tuesday } 17^{\text {th }} \\
\text { June } 2014 \\
\text { at 04:00 AM }\end{array}$ & $\begin{array}{ll}- & \text { TOUKARA Issa (30 years) } \\
- & \text { FOFANA Djeneba (29 years) } \\
- & \text { COULIBALY Korotoum }(25 \text { years }) \\
- & \text { SOUMAHORO Fatoumata (04 years) }\end{array}$ & Ivorian \\
\hline $\begin{array}{c}\text { Mossikro } \\
\text { (unspecified) }\end{array}$ & 64.7 & 05 & $\begin{array}{c}\text { Wednesday } 18 \\
\text { June } 2014 \text { from } \\
\text { 03:30 AM to 04:00 AM }\end{array}$ & Unknown identities & Unknown \\
\hline $\begin{array}{l}\text { Mossikro } \\
\text { (Boribana) }\end{array}$ & 61.4 & 06 & $\begin{array}{l}\text { Thursday } 19^{\text {th }} \text { to } \\
\text { Friday } 20^{\text {th }} \text { June } \\
2014 \text { at } 4 \text { AM }\end{array}$ & $\begin{array}{ll}- & \text { OUMAROU Ibrahim (28 years) } \\
- & \text { DALLOU Yacouba (26 years) } \\
- & \text { ABDOUL Karim (19 years) } \\
- & \text { MAMADOU Aminou (25 years) } \\
- & \text { Moussa SAIDOU (30 years) } \\
- & \text { YAHAYA Ibrahima (17 years) }\end{array}$ & Ivorian \\
\hline
\end{tabular}

Source: City Hall Technical Service 2014-2015. 
Table 10. Overview of injuries in the various neighbourhoods following the landslides in Attécoubé.

\begin{tabular}{cccc}
\hline NEIGHBOURHOODS & RAIN IN $(\mathrm{mm})$ & NUMBER OF WOUNDED & DATES \\
\hline Banco Nord & 84.9 & 04 & $05^{\text {th }}$ June 2014 \\
Santé 3 (Safari sector) & 71.1 & Undetermined (several) & Tuesday, $17^{\text {th }}$, June 2014 \\
Mossikro (unspecified) & 64.7 & 04 & Wednesday $18^{\text {th }}$ June 2014 \\
Mossikro (Boribana) & 61.4 & Undetermined (several) & Thursday $19^{\text {th }}$ and Friday $20^{\text {th }}$ June 2014 \\
\hline
\end{tabular}

Source: City hall technical service 2014 and 2015.

Table 11. Overview of damage by neighbourhood as a result of the landslides in Attécoubé.

\begin{tabular}{cccc}
\hline NEIGHBOURHOOD & RAIN IN $(\mathrm{mm})$ & DAMAGE & DATES \\
\hline Banco Nord & 84.9 & $\begin{array}{c}\text { 01 house of 02 rooms destroyed } \\
01 \text { yard with } 03 \text { doors } \\
\text { destroyed + various materials }\end{array}$ & Tuesday $17^{\text {th }}$ June 2014 \\
Santé 3 (Safari sector) & 71.1 & 02 houses destroyed & Wednesday $18^{\text {th }}$ June 2014 \\
Mossikro (unspecified) & 64.7 & 01 Koranic mosque & $19^{\text {th }}$ Thursday and \\
Mossikro (Boribana) & 61.4 & Friday $20^{\text {th }}$ June 2014
\end{tabular}

Source: Technical service of the town hall 2014 and our investigations 2015.

Table 12. Overview of landslide-related loss of life at Attécoubé.

\begin{tabular}{|c|c|c|c|c|c|}
\hline NEIGHBOURHOOD & $\begin{array}{l}\text { RAIN IN } \\
(\mathrm{mm})\end{array}$ & DATES & NUMBER OF DEATHS & VICTIMS & NATIONALITY \\
\hline $\begin{array}{c}\text { Loukoukro } \\
\text { (Djene Ecare) }\end{array}$ & & $\begin{array}{l}04^{\text {th }} \text { and } 05^{\text {th }} \text { June } 2014 \\
\text { (night from Wednesday } \\
\text { to Thursday) }\end{array}$ & 02 & $\begin{array}{l}\text { 01 Unknow ( } 30 \text { years) } \\
\text { - } \quad \text { SOUMARE } \\
\text { Mohamed (35 years) }\end{array}$ & $\begin{array}{l}\text { Unknown } \\
\text { Ivorian }\end{array}$ \\
\hline $\begin{array}{c}\text { Santé } 3 \\
\text { (Deinde sector) }\end{array}$ & 84.9 & $\begin{array}{l}05 \text { and } 06^{\text {th }} \text { June } 2014 \\
\text { (night from Friday } \\
\text { to Saturday) }\end{array}$ & 04 & $\begin{array}{ll}- & \text { YANE Seydou (13 years) } \\
- & \text { COULIBALY Yaya (04 years) } \\
- & \text { COULIBALY Tenan (07years) } \\
- & \text { YANE Madjara (38 years) }\end{array}$ & Ivorian \\
\hline
\end{tabular}

Source: Technical service of the town hall 2014 and our investigations 2015.

Table 13. Overview of landslide injuries in Attécoubé.

\begin{tabular}{cccc}
\hline NEIGHBOURHOOD & RAIN IN $(\mathrm{mm})$ & WOUNDED & DATE \\
\hline Santé 3 (secteur Deinde) & 84.9 & $\begin{array}{c}\text { 04 (Mr. BILE } 57 \text { years, } \\
\text { one of the wounded identified) }\end{array}$ & $05^{\text {th }}$ and $06^{\text {th }} \mathrm{June}^{2014}$ \\
\hline NEIGHBOURHOOD & RAIN IN $(\mathrm{mm})$ & DAMAGES & DATE \\
\hline Loukoukro (Djene Ecare) & 84.9 & $\begin{array}{c}01 \text { housing } \\
\text { destroyed + various materials } \\
02 \text { rooms }\end{array}$ & $04^{\text {th }}$ and $05^{\text {th }} \mathrm{June}^{2014}$ \\
Santé 3 (Deinde sector) & & destroyed + various materials & $05^{\text {th }}$ and $06^{\text {th }} \mathrm{June}^{2014}$ \\
\hline
\end{tabular}

Source: Technical service of the town hall 2014 and our investigations 2015.

Table 14. Overview of material damage following landslidesnto Attécoubé.

\begin{tabular}{cccc}
\hline NEIGHBOURHOOD & RAIN IN $(\mathrm{mm})$ & DAMAGES & DATE \\
\hline Loukoukro (Djene Ecare) & 01 housing & $04^{\text {th }}$ and $05^{\text {th }}$ June 2014 \\
Santé 3 (Deinde sector) & 84.9 & destroyed + various materials & 02 rooms \\
& & destroyed + various materials & $05^{\text {th }}$ and $06^{\text {th }}$ June 2014 \\
\hline
\end{tabular}

Source: Technical service of the town hall 2014 and our investigations 2015. 
Faced with such a reality of natural disasters, relief actions and financial support have been carried out.

Who are the perpetrators and beneficiaries? How much assistance can we assess for victims?

\subsection{Relief, Aid and Support Measures for Victims and Survivors of Natural Disasters in Abobo and Attécoubé}

These include aid and donations to disaster victims during and after floods, landslides and mudslide. This assistance is provided by the people, charities, municipal and government authorities.

\subsubsection{About the Population in the Two Municipalities Studied}

People in disaster areas did not sit idly by during and after the accidents. They expressed a desire to help each other. Also, the victims received from their hands from other populations; food and material of primary necessity. These include mattresses, bed sheets, loincloths, rice, mats, shoes, etc. There was no deduction in cost, because it was voluntary acts between neighbourhood brothers.

In Abobo, for example, two NGOs, Lion's Club and the Red Cross, have relieved more than 500 households by bringing them food and non-food items. These donations are estimated at tens of millions. However, they could not be valued in cash.

\subsubsection{Actions of Government Authorities}

\section{In Attécoubé,}

Given the scale of the crisis, the State has instituted a management of the people affected to the tune of 533,866.77 USD. This included accommodation (maximum duration of 03 months) for 66 people (including 15 for the municipality of Attécoubé alone). Thus, it is made available to them Assistance Kits which included assistance for the resettlement of the victims, according to the municipality of Attécoubé.

- Many gifts make a living, including rice bags, boxes of powdered milk, cartons of oil, boxes of tomatoes and pasta. All these donations are estimated at 12,979.13 USD.

- Assistance to bereaved families in the amount of 1854.16 USD each. For the 23 we count 42,636.24 USD.

In addition, the State has also committed to pre-finance the new rents of the victims to the tune of 03 months of guarantee and 02 months of rent paid in advance due to 370,841 USD per month.

In order to avoid similar disasters in the rainy season, a programme to assist people to evacuate dangerous sites was drawn up by an interdepartmental committee. However, the evacuation of exposed populations is difficult to implement due to lack of financial means. The different aspects of this program are:

- Demolition of houses, threatened houses and relocation of residents at an estimated cost of 56,264.10 USD; 
- Transportat costs, personal effects $=0.05560$ USD per household for moving expenses;

- For the 1947 households of the said municipality, the amount is $108,301.55$ USD;

- Resettlement assistance: 03 months of security 02 months of rent or 185.40 USD for $1947=360,824.12$ USD;

- Providing land parcels to resident landowners, with the State having a land reserve of 11 hectares on the Biabou side.

\section{In Abobo}

The State has distributed dignity kits (recasement aid or allowance) to the affected populations to meet immediate needs. 278.10 USD were distributed to 1.003 households or an amount of 278,933.32 USD.

The State has also made donations of live and not food to the 10 neighborhoods most affected by the hazards (Nest of doves; Houphouët Boigny; Glacier; Monastery, Red plate, Netherlands, cayman lake, Nanti, Banco, Anonkoua village). Table 15 is an inventory of donations made.

\subsubsection{Actions of Local Authorities}

\section{In Attécoubé}

- Disaster assistance: 278.09 USD to 606 people, for a total of 166,878.62 USD.

- Donations of food and non-food items for which the cost is not estimated.

\section{In Abobo}

The municipality first identified public schools to provide shelter to victims. Stadiums, hospitals, etc., have been requisitioned for this purpose. In addition, these victims have benefited from the food and non-drinking estimated at millions.

Table 15. Overview of state donations in 2014.

\begin{tabular}{cc}
\hline DONATIONS & QUANTITIES \\
\hline Mattress & 280 \\
Seals & 460 \\
Plastic basins & 460 \\
Blankets & 470 \\
Mosquito nets & 460 \\
Kettles & 460 \\
Riz Rice & 485 bags of 50 kg or 10 tonnes \\
Tomato & 470 boxes \\
Oil & 280 bottles \\
Sugar & 47 boxes \\
Milk & 47 boxes \\
\hline
\end{tabular}

Source: Our surveys 2014 and 2015. 


\section{Conclusion}

The year 2014 was the scene of hydrometeorological accidents where major material damage and loss of life were recorded. The human toll was heavy in both municipalities. More than 20 people perished under the rising water, landslides and landslides, not to mention numerous material damage recorded. It is also a very dramatic situation which has been plagued with heavy expenditures by the authorities and the population.

However, the scale of the crises in 2014 made the policy aware that the torrential rains are a serious problem for its municipalities. Thus, initiatives have been taken by these companies to anticipate and manage the impacts of bad weather. One of the actions taken is the release of the Gobelet districts in early 2015 by the Minister of Environment and Urban Sanitation and the destruction of the fence of ALPHA Blondy located on the natural drain of water in Bonoumin (Riviera 2) in Cocody. As for Attécoubé and Abobo, after several resistance attempts, the operation was finally implemented.

At the end of this study, the aim is to reinforce the operation of getting rid of occupied non aedificandi neighbourhoods for the constructions and the monitoring of the specifications for the occupation of urban spaces in order to avoid possible risks and their enormous damage.

\section{Conflicts of Interest}

The authors declare no conflicts of interest regarding the publication of this paper.

\section{References}

Abé, J. (2005). Contribution to Knowledge of the Morphology and Sedimentary Dynamics of the Ivorian Coast (Case of the Abidjan Coast). Modeling Tests for Rational Management (337 p). State Thesis. Ivory Coast: Cocody-Abidjan University.

Adomon, A. A., Emillienne, B., \& Tere, G. (2018). Communities Decentralized in Front of Urban Disorders in Abidjan. The Case of Riviera-Bonoumin in the Municipality of Cocody (Côte d'Ivoire). Current Urban Studies, 6, 121-137. Http://www.scirp.org/

Alla, D. A. (2013). Natural Hazards in the Agglomeration of Abidjan (Côte d'Ivoire) (385 p). State Doctoral Thesis. Abidjan: IGT (Institute of Tropical Geography), Félix Houphouët Boigny University.

Assako, R.-J. A. (1996). Contribution of Remote Sensing and GIS in the Search for Constructible Areas of an Urban Hill Site: The Case of Yaoundé (Cameroon). Douala.

Bailly, S. A. (1996). Environment, Natural Risks, Social Risks in Natural Risks, Social Risks. Paris Economica, 103 p.

Brou, K. M. (2008). Risks of Natural Origin in Urban Areas: The Case of Floods in the Town of Cocody (145 p). Master's Thesis. Abidjan: IGT (Institute of Tropical Geography), Félix Houphouët Boigny University. (Unpublished)

Brou, K. M. (2015). Urban Growth and Natural Risks in Mountain Environments: The Example of Man (Côte d'Ivoire) (303 p). Single Doctoral Thesis. Abidjan: IGT (Institute of Tropical Geography), Félix Houphouët-Boigny University.

D’Ercole, R. (1996). Vulnerability to Natural Risks in Urban Areas: Effects, Factors and 
Social Responses. Cahiers des Sciences Humaines, 32, 407-442.

Ramade, F. (2006). Natural Disasters (258 p)? Paris: Dunod.

Robin, M., \& Hauhouot, C. (1999a). The Urban Risk Generated by Coastal Erosion of Partially Anthropogenic Origin: The Case of the Bay of Port-Bouët, Abidjan, Côte d'Ivoire. Coast GIS'99, Session 10, 11 p.

Robin, M., \& Hauhouot, C. (1999b). Coastal Natural Risks in Côte d'Ivoire (n ${ }^{\circ}$ 51, pp. 169-185). In Ivorian Geography. Nantes Notebooks, Nantes.

Tamboura, A. T. (2008). Risks and Crises Linked to Torrential Rains in Abidjan: Case of the Commune of Attécoubé (113 p). Master's Thesis (Geography). Abidjan: University of Abidjan-Cocody. (Unpublished)

Veyret, Y., \& Nancy, M. R. (2004). Geography of Natural Risks in France (p 251). Paris: Hatier. 